\title{
Study on Enterprise Cash Flow Problems and Countermeasures
}

\author{
Mei Li \\ Shandong Yingcai University, Ji'nan 250000, China
}

\author{
Keywords: Enterprise; Cash flow; Problem; Countermeasure
}

\begin{abstract}
The enterprise is a cell of society and core force of economic development. Under increasingly fierce competition salutation, enterprises are faced with complex and changing living environment. For enterprises, cash flow truly reflects enterprise operation conditions. To some extent, cash flow can indicate debt repayment ability and operation situation of an enterprise. This paper briefly summarizes the implication of cash flow and cash flow management importance, points out the problems of cash flow management in collective operation process and then proposes targeted countermeasures, in the hope of providing reference suggestions for enterprises to solve cash flow management problems.
\end{abstract}

\section{Introduction}

Under market economy, enterprises need to comprehensively pay attention to their profit and loss as well as cash flow. Cash is a resource that an enterprise may transfer anytime and reflects internal potential of enterprise development. Enterprises with strong vigor often own sufficient cash payment ability. Financial theory considers cash flow refers to original power to improve enterprise value. All cash flow appreciation created by an enterprise decides enterprise value. Hence, cash flow management is a basic job in enterprise financial management and concerns enterprise stability and development. Enterprises must be based on their actual conditions, keep the best cash flow, and management cash low in a scientific and reasonable way to achieve enterprise value maximization.

\section{Implication of cash flow and importance of cash flow management}

\section{Implication of cash flow}

Cash flow refers to the sum of cash inflow and outflow in a period. Cash flow dynamically reflects economic position of an enterprise. It is a kind of currency income and expense behavior which can ensure and control economic activities. Cash flow may be popularly understood as the cash in the state of motion. Financially, cash flow includes all cash and cash equivalents. Cash flow reflects enterprise vigor and competitiveness and also predicts financial condition and operational risk of an enterprise. The purpose of financial management is to create enterprise value. The acquisition of enterprise value needs to depend on profitability, assets management efficiency and marketing ability. they are finally reflected in cash flow.

\section{Importance of cash flow management}

The importance of enterprise cash flow management is mainly reflected in three aspects, as follows:

Firstly, doing well cash management is a basic move for enterprises to seek survival and stable development. For any enterprise, cash demand is different in diverse development stages. Cash flow demand present stage features. For example, American W. T. Grant was one of the largest commercial enterprises, but it went bankrupt due to cash flow problem.

Secondly, enhancing cash flow management can provide long-term power for stable enterprise development. In view of flexible profit calculation method, some enterprises cut down expenses for product development link in order to pursue profit. Superficially, such practice saves enterprise cost and improves profit, but actually play no role for long-term profit. Thus, enterprises cannot form favorable evaluation index in terms of enterprise development ability. But, cash basis can well settle this problem. 
Thirdly, enhancing cash flow management can create enterprise value and improve market competitiveness. Rapid market development puts forward higher requirements for enterprises. Under such environment, enterprises must own sufficient cash flow as the guarantee in order to realize rapid development. As for profits, cash flow directly reflects debt repayment ability of an enterprise. Modern financial theory mentions appreciation caused by cash flow sum in a period reflects enterprise value. It is also power support for an enterprise to improve self-value.

\section{Cash flow problems in specific operation}

\section{Poor control of working capital results in poor capital turnover}

In an enterprise, working capital occupies the largest proportion in all funds. Thus, favorable working capital control ability and good operation of enterprise working capital play an important role for enterprise production, operation and stable development. However, some enterprises fail to cognize the functions of working capital, lack correct prediction of working capital demand and daily management of funds, thus leading to poor capital turnover and reduction of cash flow management efficiency. Many enterprises fail to manage well capital circulation and operation, purely pay attention to total assets and business volume and lack attention to importance and virtuous circle of cash flow, which results in poor cash turnover. Enterprises should guarantee favorable cash flow circulation as far as possible and make cash flow rationally allocated to each aspect. Therefore, improving enterprises' control capacity for working capital is an important job of cash flow management.

\section{Unreasonable investment activities lead to cash flow problems}

Enterprise investment refers to all behaviors to create resource appreciation. The purpose of enterprise investment plan is to pursue income maximization under fixed resource investment, or to minimize resource investment when the income is certain.

When an enterprise starts to carry out investment plan, it will be faced with inconsistent resource investment and return and disproportionate investment and return. For example, sometimes, actual investment exceeds the expectation, but the rate of return is lower than the expectation. Many enterprises still fail to adjust their investment decisions in the face of these situations and fail to well management expenditure. Instead, they increase capital investment to expect higher rate of return to solve such plight. In fact, such practice will make them suffer the awkward situation of vicious capital increase. In addition, many companies fail to do market research preparations well in project investment, blindly follow suit and lack prediction of future risks and precautions.

\section{Capital raising and use lack scientificity}

Scientific and reasonable capital raising and use can guarantee healthy and stable enterprise operation. Objectively, the shortage of capital raising channels is ubiquitous for numerous enterprises. For enterprises, the finally financing quantity is small and the cost is high $f$ they only depend on financial channel for financing. Enterprises lack financing plans in operation period. When sellers' market transforms to buyers' market, the supply of products will surpass the demand, which will result in profit decline and cash raising difficulty. Enterprises often the way of robbing Peter to paying Paul, thus leading to the risk of income and expense capital-raising risk and the increase in debt disputes. This affects national normal financial sequence. Subjectively, one of the causes for the difficulty in financing is the lack of rational financial management. After some enterprises apply for bank loans, they fail to provide financial statements in time as required by the bank. Some even provide temporary and false statement information.

\section{Study on countermeasures of enterprise cash flow problems}

To enhance daily management and improve cash low problems in operation activities

In daily financial management, enterprises should improve from such aspects as management consciousness, management work, cash journal system and cash in bank journal, as follows:

Enhance cash flow management consciousness 
First of all, it is required to correct the attitude to making cash flow statement. Cash flow statement should be prepared well monthly. In-process control and post-analysis should be done well. Secondly, financial personnel and management personnel should be trained to improve their quality and make them gradually attach importance to cash flow, on longer purely concern profit and ignore cash flow information.

Reinforce receivable management

Firstly, receivable recovery period should be shortened as far as possible. Cash discount may be adopted to shorten receivable recovery period and make buyer's payment deadline ahead of time. It is required to check loan recovery schedule regularly and make recovery time in advance as far as possible. Secondly, it is required to make clear management duties of receivable post, arrange special persons o manage receivables, check receivable age and the cause and reduce "bad debts". Credit management personnel should investigate customers' credit in advance, effectively manage receivables and carry out in-process tracking and post-inspection and recovery for receivables. It is required to get along well with the customers and reduce enterprise credit risk to the largest degree. Besides, enterprise cash flow, inventory, sales and receivables should be focused on in time to avoid the difficulty in recovering receivables.

Gain banks' trust

Cash journal system and cash in bank journal should be done well. Keeping good contact between enterprises and banks, timely account checking and settlement, forming good credit image in banks and improving integrity degree and credit line play an important role in further expanding financing channels. Meanwhile, these contribute to enterprises to improve operation mode and provide financial support.

\section{To improve countermeasures for cash flow management in investment activities}

To improve countermeasures for cash flow management in investment activities and reduce cash flow risks is an effective approach to ensure normal enterprise cash flow. The details are as follows:

(1) Strictly control expenditure. During implementation of investment plans, enterprises should notice cash expenditure and make timely adjustment in case of any problem to avoid vicious capital increase.

(2) Inward investment way is dominated. Inward investment includes the following modes: 1) funds are invested in new product development; 2) funds are invested in technology equipment upgrade; 3) funds are invested to human resource construction. The increase in human resource can introduce a batch of high-quality technology and management personnel which become a magic weapon for success in a sense.

(3) Decentralize investment channels and reduce investment risks. When enterprise funds accumulate to certain degree, they may try diversified operation and adopt the mode of "placing eggs into different baskets" to reduce investment risks.

(4) Standardize project investment procedure. When enterprises own mature funds, technology and management ability, they may adopt investment management mode to supervise various investment activities, elaborately plan and implement each stage.

\section{Countermeasures to improve cash flow management in financing activities}

For enterprises, favorable financing structure and proper dividend distribution can optimize enterprise cash flow management from the perspective of financing activities. The details are as below:

Establish rational financing structure. Enterprises construct good financing structure, rationally utilize operation on borrowings and carry out the best operation mode of "laying eggs by borrowing others' chicken "existing conditions” and "repayment of chicken with eggs”. Enterprises should start from their repaying ability, raise sufficient funds, and avoid seeking quick success and instant benefits and blind loans. Enterprises' financing activities should be standardized to cut down enterprises' benefit shunt and boost debt repaying ability. Besides, finance department should establish the financing credit, form virtuous circle of "borrowing-repaying-borrowing", and pay attention to banks' credit and commercial reputation. 
Adopt moderate dividend distribution. During formulating dividend distribution system, enterprises should not merely solicit internal opinions, but also tale into account of external environment requirements. Enterprises should formulate fair and reasonable dividend distribution system, adopt suitable distribution principle and closely link cash flow of operation and income. Based on enterprise operation situation, when there is short of investment opportunities with strong debt-repaying ability, stable capital flow and income and low financing cost, income distribution policy may be properly loosened, and cash dividend payment mode may be applied. If an enterprise tightens income distribution policy, cash dividend payment will decrease. Besides, when inflation results in the decrease in purchasing power and the difficulty in capital resetting, more profits will be embezzled to compensate. Then, the enterprise will tighten income distribution policy.

\section{To set up internal supervision system for cash flow}

Favorable internal supervision system is an important guarantee for enterprise normal cash flow and contributes to improving enterprise decision-making rationality. Meanwhile, all kinds of expenses and saving can be made clear to effectively avoid corruption and embezzlement of cash etc. The details are as follows:

Supervise internal control activities

Main contents are as below: prepare cash budget in advance and adjust implementation plan in real time; supervise profit inflow process; supervise the process and necessity of outward financing activities; supervise daily expenditure; supervise expenditure decisions; supervise and manage company properties such as cash on hand and deposit in bank.

Establish internal control system for cash flow

On the one hand, cash use range may be stipulated, and internal entanglement system may be set up to ensure cash security. For instance, various expenditure standards ca be formulated in advance to save expenditure, avoid corruption and embezzlement of funds; on the other hand, it is required to control and manage enterprise cash flow activities. A set of suitable and complete supervision system should be constructed. Meanwhile, procurement activities should be supervised strictly to reduce unnecessary cash payment and accurately estimate payment time.

\section{Conclusions}

In one word, the study on enterprise cash flow management has become a significant research topic in financial management subject. It is required to correctly cognize connotation and importance of enterprise cash flow, specify prominent problems in cash flow management link and propose corresponding countersues. This is an important task fort current enterprise financial management. Cash flow management work should be persisted for a long time. With changes in internal and external environment as well as enterprises' strength changes, corresponding adjustment should be made to ensure rational operation of enterprise funds.

\section{References}

[1] Zheng Zhizhong, Xiang Jing, Xiong Yan, Reasons and countermeasures of enterprise cash flow shortage. Financial Economy, 2013,22:227-229

[2] Zhang Cheng, Problems and researches of enterprise cash flow management. Foreign Investment in China, 2014,04:115+117

[3] Wang Gaofeng, Effects of Commercial draft settlement on enterprise cash flow statement and countermeasures. Times Finance, 2014,03:236+244

[4] Wang Qiang, Problems and researches of cash flow management in small and medium enterprises. Manager's Journal, 2014, 05:86

[5] Wang Peijin, Problems and researches of cash flow management in small and medium enterprises. Money China (Academic Edition), 2013, 15:65+137 
